\title{
A bargaining and property rights perspective on the Belt and Road Initiative: Cases from the Italian port system
}

\author{
Cristian Luise ${ }^{1,2}$, \\ Peter J. Buckley ${ }^{1}{ }^{\circ}$, \\ Hinrich Voss ${ }^{3}$ (0, \\ Emmanuella Plakoyiannaki ${ }^{4}$ \\ and Elisa Barbieri ${ }^{5}$
}

\footnotetext{
${ }^{1}$ Leeds University Business School, University of Leeds, Leeds LS2 9JT, UK; ${ }^{2}$ Department of Management, Cà Foscari University of Venice, Canareggio 873, Fondamenta San Giobbe, 30121 Venice, Italy; ${ }^{3}$ HEC Montreal, Montreal, Canada; ${ }^{4}$ Chair of International Business, Department of Marketing and International Business, Faculty of Business, Economics and Statistics, University of Vienna, Oskar-

Morgenstern-Platz 1, 1090 Vienna, Austria;

${ }^{5}$ Department of Economics, Cà Foscari University of Venice, Canareggio 873, Fondamenta San Giobbe, 30121 Venice, Italy
}

Correspondence:

H Voss, HEC Montreal, Montreal, Canada e-mail: hinrich.voss@hec.ca

\begin{abstract}
Infrastructural assets are vital for a country's economic and social development. Governments typically provide the regulation and administration of these assets, while multinational enterprises (MNEs) develop, construct, finance, and operate them. The Belt and Road Initiative (BRI) promises infrastructure projects that deliver economic and social benefit for both the host country and the MNE, however, the foreign market entry activities of Chinese MNEs in infrastructure projects might not always be successful. By bridging the bargaining power literature with the economics of property rights perspective, we examine how and why host-country actors at different governance levels influence foreign direct investment. Using a comparative case study approach, we interrogate four attempts by Chinese firms to negotiate access to Italian ports. In particular, we show that for a BRI port investment to take place, there has to be an alignment between the various actors of the property rights nexus regarding the allocation of rights. Chinese investors need to understand the bargaining position and property rights of actors across multiple levels, across space, and be mindful of changes over time when negotiating an infrastructure investment. Host-country governments need to have a clear port infrastructure strategy to avoid wasting resources in lengthy negotiations and useless infrastructure.

Journal of International Business Policy (2022) 5, 172-193.

https://doi.org/ | 0. 1057/s422 I 4-02 I-00 I22-9
\end{abstract}

Keywords: bargaining theory; Belt and Road Initiative; emerging market multinationals; FDI policy; infrastructure; property rights economics

\section{INTRODUCTION}

Infrastructural assets are vital for a country's economic and social development (UNCTAD, 2008). Governments typically provide the regulation and administration of these assets, while (multinational) enterprises (MNEs) develop, construct, finance, and operate them (Dykes, Stevens, \& Lahiri, 2020; Müllner, 2017). Infrastructure projects under the Belt and Road Initiative (BRI) broadly follow the same structure but have the Chinese government ultimately providing the finance.

Scholars have paid attention to many issues related to BRI infrastructure projects such as host-country debt accumulation
Received: 1 March 2020

Revised: 11 August 2021

Accepted: 9 September 2021

Online publication date: 25 November 2021 
(Hurley, Morris \& Portelance, 2019; Rajah, Dayant, \& Pryke, 2019) and national sovereignty and oversight (Narins \& Agnew, 2020). This body of work seemingly takes it for granted that Chinese firms can develop infrastructure projects or enter into existing ones in overseas markets. Yet, the cautionary tales from a variety of BRI projects such as the Khorgos Gateway in Kazakhstan (Standish, 2019), the Kyrgyzstan free trade zone (Shepard, 2020), or the Malaysian projects (Liu \& Lim, 2019) point to the possibility that the anticipated economic and social benefits may not readily materialize and that a BRI project may not be easily implemented - even when the project creates new infrastructure like the Port of Gwadar and the China-Pakistan Economic Corridor. It is therefore likely that potential Chinese investors face even greater challenges when they attempt to develop infrastructure when there is already an established stock of infrastructure in the host country. In either case, the governance structure across the various operational and constituent elements of infrastructure are critical to its functioning and need to be understood, negotiated, and managed by an MNE so as to develop a successful infrastructure project.

The potential challenges that BRI projects and Chinese investors face resonate with calls from international business (IB) researchers to analyze MNE entry in foreign countries in a more realistic manner (e.g., Benito, Petersen, \& Welch, 2009, 2011, 2019) and to implement perspectives that avoid taking purely MNE-centric analyses (Hennart, 2009; Müller \& Puck, 2018). Existing research on the modality of the BRI has largely taken a Chinese government and/or business-centric approach (Buckley, 2020a, b; Gong, 2019; Sutherland, Anderson, Bailey, \& Alon, 2020; Yu, 2017) and investigated Chinese government objectives (Summers, 2016; Tekdal, 2018). This approach has revealed relatively little about how BRI actors negotiate with local asset owners, private or public, related actors, and the policy and political challenges that they face overseas.

Using bargaining theory and property rights theory, we assess how Chinese firms have attempted to negotiate access to overseas infrastructure projects. We employ a comparative case study (CCS) approach (Bartlett \& Vavrus, 2016), analyzing the entry process as an outcome of interdependent negotiations across four Italian ports between 2010 and 2020 and across three levels of analysis, namely the country level (national government), port authority, and investment/port level. Our analysis attributes agency to both governmental and non-governmental entities in the host country. Our research sheds light on the challenges MNEs and host-country actors encounter during the investment negotiation process because the investment negotiations include more actors than the immediate property rights holders. It is therefore our contention that the negotiation between the investor and the local actors does not take place within a vacuum but that it is essential to account for the existing nexus of contracts and property rights in the host country in order to comprehend the opportunities and difficulties faced by foreign investors in overseas infrastructure projects.

In our framework, we move away from considering the host country as a homogenous singularity and from considering BRI infrastructure projects as driven by Chinese interests. Our analysis shows that the interaction of Chinese policy, local and national host-country governmental bodies and the action of corporate entities all co-determine the outcome. From a bargaining perspective, this suggests that actors within the host country shape the policy environment for foreign investors and that such investors have to understand all the relevant actors and their objectives before an investment is undertaken. Potential entrants need support in understanding the new business environment, the nexus of contracts and property rights they will encounter and, in light of this, how to position and develop their bargaining strategy.

These insights make a theoretical contribution by integrating bargaining and property rights theory and applying them to both successful and unsuccessful instances of foreign entry. We contribute to the literature on policy making by including concrete institutions and bargaining processes in a model that puts bargaining center stage in the analysis of FDI in infrastructure projects.

In the next section, we discuss the theoretical background and relate it to existing work on the BRI. We then present an in-depth description of the research context followed by the research method. A discussion of our findings and implications for research and practice conclude the paper. 


\section{THEORETICAL BACKGROUND}

\section{MNE Entry and Infrastructure Assets: Bargaining with Host-Country Actors}

Bargaining power perspectives have been used by IB scholars to explain MNE's foreign activities and their interactions with host-country actors (Boddewyn, 2005, 2016; Grosse, 2005). This literature dates back to the work of Vernon (1971), who developed the obsolescing bargaining argument. The MNE is able to obtain a favorable initial investment deal thanks to its resources (e.g., technology and financial strengths), that obsolesce over time. The host government accretes bargaining power over time after the physical investments have been made as the MNE is now captive and can be subject to changes in policies that favor the host country. Early studies developed this argument along two lines of research. In the first, scholars used several proxies for firm-level (e.g., technological resources, product differentiation, export intensity) and host-country resources as antecedents of MNE and host government power. The ownership and control configuration of the investment then determined the initial investment configuration (Fagre \& Wells, 1982; Kobrin, 1987; Lecraw, 1984). A second line of enquiry tried to test the obsolescing hypothesis by employing longitudinal research (Jenkins, 1986; Moran, 1974; Vachani, 1995). Although this literature has provided grounds for developing a bargaining power model to determine the initial investment configuration, it reveals little about how the negotiation for foreign investments unfolds over time, who the actors involved are, and why certain negotiations fail. In particular, a common assumption was to consider the investment configuration as determined between the MNE and the host-country government only. This neglected the fact that assets might be owned by private actors and/or local governments and it did not account for the interests of actors at different governance levels (Ritvala, Granqvist, \& Piekkari, 2021; Stopford \& Strange, 1991).

Scholars have tried to improve bargaining theory by building upon the obsolescing model. Grosse and Behrman (1992) proposed a bargaining model as a general theory of IB about multilateral negotiation over the distribution of benefits and costs between firms and governments. In line with previous models (Kindleberger, 1969; Kobrin, 1987; Moran, 1974), the outcome of the negotiation between the MNE and host government is presented as a function of the relative bargaining power that is determined by the alternatives the two parties have outside the negotiation, the perceived value of the other party's resources, and the interdependencies with other actors (Grosse \& Behrman, 1992). Despite examining bargaining as a multilateral distribution of costs and benefits between firms and governments, the model presents several limitations. Firstly, the theoretical mechanisms that determine power remain at the dyadic level and account for the role and influence of actors at different governance levels only indirectly. For instance, we cannot assume that the negotiation happens only between a central monolithic government and one or more MNEs because we have to account for the influence of the local governments and other local agencies on the distribution of costs and benefits. Secondly, power of the various parties and hence the strategies and policies that can be used vary over time. This implies that power should be derived endogenously by accounting for the dynamic unfolding of the negotiation. Determining ex-ante the power of the various parties according to given antecedents does not fully explain how and why certain negotiations succeed or fail.

More recently, scholars have developed models to grapple with the complexity of the bargaining process and to account for the dynamic nature of the negotiations and for the strategies that the actors employ. Ramamurti (2001) updated Vernon's $(1971,1981)$ classic one-tier bargaining model to acknowledge that the MNE's homecountry government bargains with the host-country government with the support of international organizations (e.g., World Bank and IMF) to create a favorable environment within which its MNEs can negotiate. MNEs will only negotiate with hostcountry governments once the first stage has been accomplished and implemented. Proposed a political bargaining model where MNEs and host governments bargain continuously over policies. The theoretical mechanisms correspond to those of Behrman and Grosse (1992) - and so do the limitations of this model. Nebus and Rufin (2010) used network theory to predict which actors would be able to influence the overall bargaining outcome and "win" the negotiation. Despite the model being multi-level and multi-actor, it assumes that scholars know who are the actors that take part into the bargaining and, in line with previous models, that actors can determine their positions of power by 
overlooking the dynamic nature of the actors' involvement and the strategies employed to advance their positions of power. Recently, Müllner and Puck (2018) developed a framework where MNEs and host-country governments influence each other's sunk costs and access to alternative locations to maintain the power balance in their favor by shedding light on the strategies MNEs can use. In line with the above models, Müllner and Puck (2018) assume a dyadic power balance between the MNE and the host government that is only indirectly influenced by the activities of various actors at different governance levels.

When a firm invests into, for instance, an existing port infrastructure, it is likely to use local labor to access different types of suppliers and it will try to get a concession contract from the local government. In turn, these actors have an interest in the ownership of the infrastructure as it represents the asset through which they can obtain their benefits. Thus, the bargaining perspective should include all the actors who try to capture or protect their rights over the distribution of resources that the investment encapsulates. To develop this perspective, we next turn to property rights economics.

\section{An Economics Property Rights Perspective to MNE-Host-Country Actor Bargaining}

When Coase (1959) advised the USA to use a bidding process in order to allocate radio frequencies, he tried to understand what a bidder would consider in order to make its offer. This is because it is difficult to find a price unless the actor knows which use rights have already been allocated and who might use the frequency or adjacent ones (Coase, 1959). Coase (1960) considered assets to be bundles of rights to perform certain actions instead of physical units. This helps us to understand the allocative process that would lead to a welfareincreasing "constellation of rights" (Coase, 1988, p. 12).

Alchian (1965) defined property rights as "the rights of individuals to the use of resources...supported by the force of etiquette, social custom, ostracism, and formal legally enacted laws supported by the states, power of violence or punishment" (p. 129). This definition leads to the distinction between legal property rights and economic property rights (Barzel, 1997). Economic rights have been defined as "the individual's ability, in expected terms to consume the good (or the services of the asset) directly or to consume it indirectly through exchange", while legal rights "are the means to achieve the ends" where the ends are the economic rights themselves (Barzel, 1997, p. 3 ). The key focus of property rights economics is on the multidimensional nature of ownership (Barzel, 1997; Coase, 1960; Kim \& Mahoney, 2005).

An owner of a resource holds the rights to exercise choices over goods and services (use rights) and obtain income (value appropriation rights), but to also alienate the latter rights (transfer rights) (Alchian, 1965; Foss \& Foss, 2005; Foss, Klein, Lien, Zellweger, \& Zenger, 2021). Accordingly, it is the effective control over these rights that makes someone the owner of a resource (Foss et al., 2021). Thus, the economic rights actors have over assets shifts over time because their enforcement depends not only on the legal system - which is costly and contestable - and informal institutions, but also on individual means. As put by Barzel (2015), "Suppose Congress grants me ownership over an accurately delineated chunk of the Pacific Ocean. This secures my legal rights, but what good are these rights without (costly) naval protection?" (p. 719).

The unclear delineation of property rights is related to the presence of transaction costs (Coase, 1960) that are defined as "the costs associated with the transfer, capture, and protection of rights" (Barzel, 1997, p. 4). The fact that rights over an asset might not be entirely controlled by the legal owner means that the costs and benefits related to a decision over the rights of an asset will affect other actors (Roberts \& Milgrom, 1992). These costs and benefits represent what Coase (1960) called externalities. Accordingly, actors will try to internalize externalities by means of a "...change in property rights, that enables these effects to bear in (greater degree) on all interacting parties" (Demsetz, 1967, p. 348). Thus, the property rights perspective highlights the interdependencies between production activities that might lead to externalities among actors because property rights over assets are not fully secure or clearly delineated. We can thus explain whether and how MNEs might enter or not into host countries by looking at foreign direct investment (FDI) as an internalization process of externalities where actors bargain in order to capture and protect their rights over assets.

In the next section, the connection between bargaining power perspectives and property rights will be teased out and applied to the context of Chinese MNEs investment in ports terminals and the BRI. 


\section{Chinese MNEs Bargaining for Port Infrastructures and the BRI}

We apply the above theoretical framework to the case of Italian ports to develop our argument further in this particular context before we assess (in the "Discussion" section) how the findings relate to other contexts. We address the functioning of the Italian port governance in relation to FDI in the research context section below. For now, it is sufficient to say that ports in Italy are owned by the central government and managed at the local level by port system authorities (PSAs). Terminal companies operate via concession contracts negotiated with the PSA and manage the terminal through a series of contracts with customers (shipping companies) and service providers such as labor cooperatives.

Take the example of a PSA that seeks a private investor to develop and operate its terminals. The laws of the Italian port system offer the PSA several options on how to develop the infrastructure. Common across these options is that the PSA is given the mandate to negotiate with potential investors the allocation of property rights. Yet, while the PSA might find an investor for the project, it cannot conclude the negotiations alone. The central government as the ultimate owner of the ports has to approve the allocation of property rights. In the case of the development of new infrastructure, this is required as part of the formal approval process and in the case of developing existing infrastructure the central government can intervene through the 'Golden Power' rule. 'Golden Power' gives the government the opportunity to review any transportation-related investment and establish whether it considers it to be harmful or threating "to the fundamental interests of Italy relating to the security and operation of networks and systems, to the continuity of supplies and the preservation of high-tech know-how" (Foscari, Graffi, Immordino, Seganfreddo, Storchi, \& Tosi, 2020). The government might be encouraged by competitors or shifts in the political landscape to employ its powers to stall an investment. Barzel (1997) argues that property rights over resources are unlikely to be ever fully delineated and stable. Instead, he argues, there is a constant need for actors to ensure that they capture and protect their rights appropriately as the institutional and competitive landscape evolves. The development or optimization of a terminal might alter the distribution of rights to existing actors who will, in turn, try to better protect and capture their own rights.
Competing terminal operators in the same port or competing national and international ports might try to protect their existing use and income rights through lobbying against the new investor. It is therefore important for any potential investor, but also for local actors, to understand how the current distribution of rights within the host country, and potentially beyond, can influence an investment project. Knowing the relevant actors and understanding their objectives and levers can inform the steps the investor needs to undertake to realize their investment (Beeson, 2018). This also includes understanding if and how actors at different governance levels aim to capture, protect, and distribute rights.

The ability of actors to protect and capture their rights is historically and institutionally contingent (Foss \& Foss, 2015; Kim \& Mahoney, 2005; Sened, 1997). In the instance of the application of the "Golden Power Rule", the political environment might influence the way this is applied. The competition between China and USA, and more recently also with Europe, has brought BRI and Chinese MNEs investment under intense scrutiny (Houtari, 2021). In the context of port infrastructure, the Italian government could be pressured by historical political obligations in the implementation of the rule. Further, at the national level, the central government might release a country-specific port policy for BRI investments that favors some specific ports over others. Unfavored ports might seek to protect their rights of being allowed to negotiate with Chinese investors. BRI might represent a means for China to favor the internationalization of its companies. However, its implementation has to be understood within the host country's political landscape; and its international geopolitical landscape but this is beyond the scope of the current paper ( $\mathrm{Li}$, Van Assche, Li, \& Qian, 2021). IB scholars have used political ratings or the degree of political stability of the host country to represent the influence of the host country's political environment over foreign market entry (Delios \& Henisz, 2003; Henisz \& Zelner, 2010; Holburn \& Zelner, 2010). However, the political and geopolitical dynamics behind the implementation of host and foreign policies, such as the BRI, in a host country remains unexplored.

This paper aims to fill these research gaps. Specifically, our aim is to explore how actors at different governance level engage in the bargaining process over Chinese MNEs entry; how over time the implementation of BRI influences the 
protection of rights and capture activities by the various actors; and why some processes lead to Chinese MNEs entry and others do not.

\section{RESEARCH CONTEXT}

\section{The BRI and Port Infrastructure Projects}

The concept behind the BRI was first announced by Chinese President Xi Jinping in 2013 under the labels "Silk Road Economic Belt" and the "21st Century Maritime Silk Road" and formalized in 2015. A core objective of the BRI is the development of transportation infrastructure within and between countries to support international economic cooperation and trade. Transportation infrastructure is vital to the world economy but faces an estimated annual investment shortfall of US\$ 0.35-0.37 trillion (OECD, 2018). The BRI was partially created to address this gap. The BRI and China's 13th 'five-year' plan (2016-2020) have encouraged Chinese port and terminal operators to invest overseas which "seems to be strongly embedded within geo-economic and geo-political policies of the Chinese government" (Notteboom \& Yang, 2017, p. 198). These investments are complemented and supported by 38 bilateral and regional maritime trade agreements with 47 BRI countries (Office of the Leading Group for Promoting the Belt \& Road Initiative, 2019).
Chinese investments in overseas ports started before BRI and shortly after the announcement of the 'go global' policy when Cosco Shipping Ports acquired in 2001 a majority share in the Port of Long Beach, USA (Chen, Fei, Lee, \& Tao, 2019; Voss, Buckley, \& Cross, 2009). Since then, Chinese activities in overseas ports have grown significantly. Huo, Chen, Zhang and Li (2019) recorded 39 Chinese investments in overseas ports across 26 countries between 2003 and 2017 and Liu, Schindler and Liu (2020) stated that Chinese firms have been involved in the construction of 62 ports and ownership and/or operation of 54 ports since 2000 . The main actors are the central state-owned enterprises Cosco Shipping Ports and China Merchants Port who own/operate 12 and 13 overseas ports, respectively (Huo et al., 2019), and the China Communication Construction Company (CCCC) which has been involved in the construction of 30 overseas ports (Liu et al., 2020).

\section{Investing into Italian Port Infrastructure}

Foreign investors in Italian ports have to engage with and maneuver within a wider field of stakeholders beyond just the locality in which they seek to invest. They have to involve three levels of organizations that include the national government, the responsible PSA, the port, and its local stakeholders in the investment project. These levels are intertwined, and they are engaged in

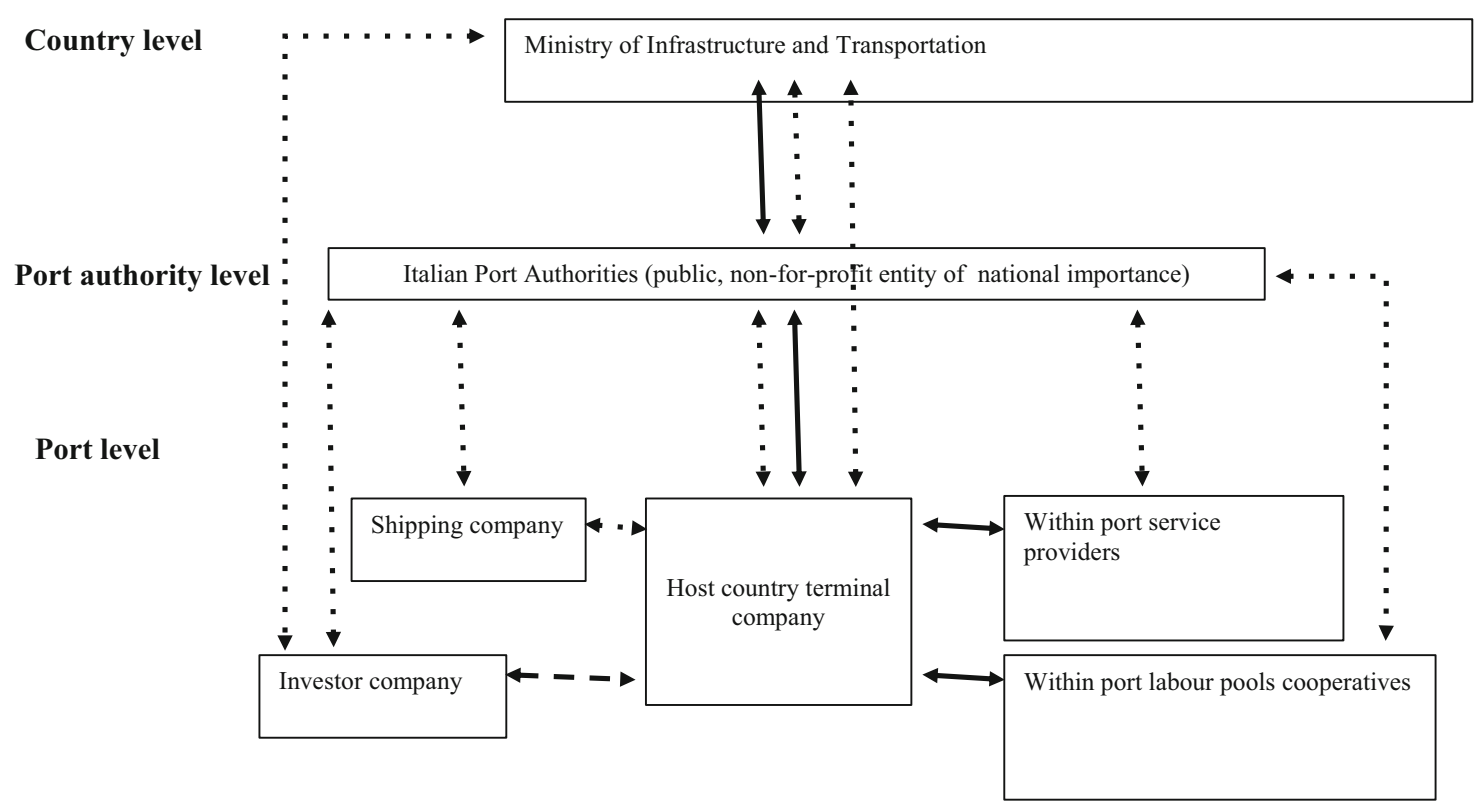

Figure 1 Italian port organization post-2016 reform. Notes solid lines: contractual relationships; dotted lines: informal relationships. Source Authors. 
supporting the local and national governments to achieve their socio-economic objectives (see Figure 1 for a stylized representation of the Italian port governance system).

At the national level, it is the Ministry of Infrastructure and Transportation (MIT) that establishes the overarching framework under which PSAs operate and manage the ports under their supervision. The recent reform of the governance of the Italian port system (legislative decree 196/ $20161^{1}$ ) in 2016 aimed at improving the competitiveness of the Italian port system in light of the dynamics in the maritime industry and brought it in line with the European Union Regulation of 2013 (Regulation No 1315/2013) concerning the Trans-European Transport Network (TEN-T). While the transnational and European levels are not the focus of the current investigation, it is important to point out that infrastructure developments in Italy and investment decisions in individual ports are embedded in a supra-national regulatory framework and policy objectives. It follows from this that the Ministry engages in economic diplomacy with other countries and concludes, for example, a memorandum of understanding (MoU) with China concerning Italy's support of the BRI.

Operations and services of ports are delegated from the Ministry to one of the 15 PSAs that were established in 2016; reduced from previously 24 PSAs. PSAs compete against each other and have the power to authorize usage of the port and award concessions for commercial and industrial activities to investors. The Port Regulatory Master Plan ["Piano Regolatore Portuale" (PRP)] defines investments and development opportunities, and, after the 2016 reform, the PRP is approved by the Region and it is subject to agreement firstly with the municipality and secondly with the MIT, whose decision is taken after the opinion expressed by the conference of PSAs' presidents. The functions and practices covered by Italian PSAs are characteristic of the so-called "landlord" port governance model that attributes only planning and management duties to PSAs (World Bank, 2001). More precisely, the Italian port system presents features that characterize the "Latin Tradition" (Ferrari, Tei, \& Merk, 2015). This type of governance, which can also be found in France and Spain, gives the central government greater influence in the planning of port activities and the possibility for the PSAs to facilitate and coordinate logistic connections between the port and the hinterland (Ferrari et al., 2015).
Investors and PSAs have different options to realize an investment opportunity depending on whether the port area (e.g., a terminal) has been developed or not. If the area has not been developed yet, then either the PSA can promote the development of the new area to potential investors or investors can propose to the port authority the building of a new berth and then start building the infrastructure. The investor can build the infrastructure on its own or through a public-private partnership (PPP) with the PSA. If, instead, the terminal has already been constructed, the investor might invest in a free terminal by stipulating a new concession agreement, or it can enter into an equity joint venture with the existing concessionaire. In the latter case, despite the law (articles 2498 and 2504-bis of the Italian Civil Code) does establish ex lege the continuation of all legal preexisting relationships, including the concession relationship, port authorities do usually have to agree to the change in ownership.

\section{RESEARCH DESIGN AND METHODS}

In order to analyze how the bargaining process involving Chinese MNEs entry unfolds over time and to assess the influence of BRI on the effort of the various actors of the nexus, we adopt a Comparative (multiple) Case Study (CCS) approach (Bartlett \& Vavrus, 2016) with multiple embedded units of analysis. The decisions are located at three different levels of analysis that correspond to the port, the port authority, and the country level. Table 1 illustrates the scope of the three levels and the focus of our data collection for each of them. We compare vertically and horizontally (Bartlett \& Vavrus, 2016) across our units of analysis and examine their evolution within these three levels. Vertical comparison is a useful approach as this allows us to embrace the different levels of analysis in an interdependent manner and hence to account for MNEs' entry processes as determined by the activities of different actors at different governance levels. Horizontal comparison allows us to compare the various units across the selected cases. The CCS approach is aligned with our interest in refining and extending theory via the use of the context within which the bargaining processes unfold (Plakoyiannaki, Wei, \& Prashantham, 2019).

We focus on the time period 2010-2020, which includes the organizational overhaul of Italian ports in 2016, the launch of the BRI in 2015, and Italy's subsequent endorsement of the BRI in 2019 
Table 1 Multi-level structure of Italian port governance

\begin{tabular}{|c|c|c|c|c|}
\hline $\begin{array}{l}\text { Policy/ } \\
\text { investment } \\
\text { level }\end{array}$ & $\begin{array}{l}\text { Governance } \\
\text { mechanism }\end{array}$ & Focus & Investment implications & Policy implications \\
\hline Country & $\begin{array}{l}\text { Policies and } \\
\text { institutional } \\
\text { setup }\end{array}$ & $\begin{array}{l}\text { Policy and country strategy concerning logistic } \\
\text { nodes, compliance with EU regulation, and } \\
\text { country-level economic diplomacy }\end{array}$ & $\begin{array}{l}\text { Provides an overarching } \\
\text { framework for } \\
\text { investments in Italian } \\
\text { ports }\end{array}$ & $\begin{array}{l}\text { Ultimate owner of } \\
\text { ports and arbiter }\end{array}$ \\
\hline $\begin{array}{l}\text { Port } \\
\text { authority }\end{array}$ & $\begin{array}{l}\text { Policies and } \\
\text { internal } \\
\text { regulations }\end{array}$ & $\begin{array}{l}\text { Planning, coordination, regulation, promotion, } \\
\text { and control of port operations and services }\end{array}$ & $\begin{array}{l}\text { Key central point for } \\
\text { contract system }\end{array}$ & $\begin{array}{l}\text { Primary } \\
\text { governance entity } \\
\text { of individual port }\end{array}$ \\
\hline $\begin{array}{l}\text { Port/ } \\
\text { investment }\end{array}$ & $\begin{array}{l}\text { Negotiated } \\
\text { governance plan } \\
\text { and contracts }\end{array}$ & $\begin{array}{l}\text { Negotiation over governance structure of the } \\
\text { infrastructure investment }\end{array}$ & $\begin{array}{l}\text { Agreement between local } \\
\text { stakeholders and the } \\
\text { investor }\end{array}$ & $\begin{array}{l}\text { Localized } \\
\text { operationalization } \\
\text { of governance }\end{array}$ \\
\hline
\end{tabular}

Source Authors.

(via a MoU to support Chinese investment projects in Italy). The choice of the port sector and that of Italy are motivated by the fact that some Italian ports have been part of the commercial agreements contained in the MoU and by the fact that one of the authors is academically involved in the teaching of the subject of ports and logistics at an Italian University that has facilitated the understanding of the context and data access.

\section{Case Selection}

As we were looking for revelatory cases, we purposefully selected four Chinese investments in Italian port container terminals located in four different regions and operating under different port authorities (Fletcher \& Plakoyiannaki, 2011; Piekkari \& Welch, 2011). The four cases represent almost the totality of Chinese investments or negotiation for investments in the Italian port container terminals.

The first case is that of the Venice Offshore Onshore Port System (VOOP, the Case of Venice) promoted by the Venice Port Authority. The VOOP is an off-shore container terminal platform intended to obviate the problem of sea-beds excavation within Venice lagoon to host large container carriers. The platform would be connected to an on-shore container terminal via semi-automated small barges. The project started between 2009 and 2010 and was put on hold by the Italian government in 2016. It was planned to be a Design-BuildFinance-Operate (DBFO) type of PPP with a total cost of $€ 2.1$ billion. The second case is the investment by Cosco Shipping Ports and Qingdao Port International in the Port of Vado Ligure ${ }^{2}$ in 2016 (the Case of Genoa). The two companies acquired
49 and 9.9\%, respectively, of the equity that A.P. Moller-Maersk held in APM Terminals Vado Ligure S.p.A. The latter was a temporary company association created in 2009 for executing the project financing for the design and construction of the Vado Gateway - a container terminal. The third case is that of the negotiations between China Merchants Ports and CCCC, respectively, with Piattaforma Logistica Trieste S.r.l. for the acquisition of a multipurpose terminal within the port of Trieste (the Case of Trieste). This case is an instance of failed Chinese entry. The last case is that of the port of Taranto (the Case of Taranto) where CCCC put on hold the negotiation for building a new container terminal and a logistic area. Figure 2 presents a timeline of the key events for each case and the main political changes within Italy.

\section{Data Collection and Analysis}

For the case studies, we rely on semi-structured interviews with officials from port authorities, ports, terminals, labor unions, investor groups, and sector specialists. They are complemented by archival data such as contractual agreements, port regulations, regional, national, and European policies (a total of 324 pages). We triangulated the data from these multiple sources in order to cope with the fact that our data was collected in a retrospective fashion (Poole et al., 2000). Table 2 summarizes the interviews carried out. Interviews started in 2019 with Italian and international shipping and port consultants and Italian lawyers in order to better understand the entity of the shipping and port industry dynamics. At the end of 2019, we started interviewing various port actors within the three different cases. We conducted a total of 46 

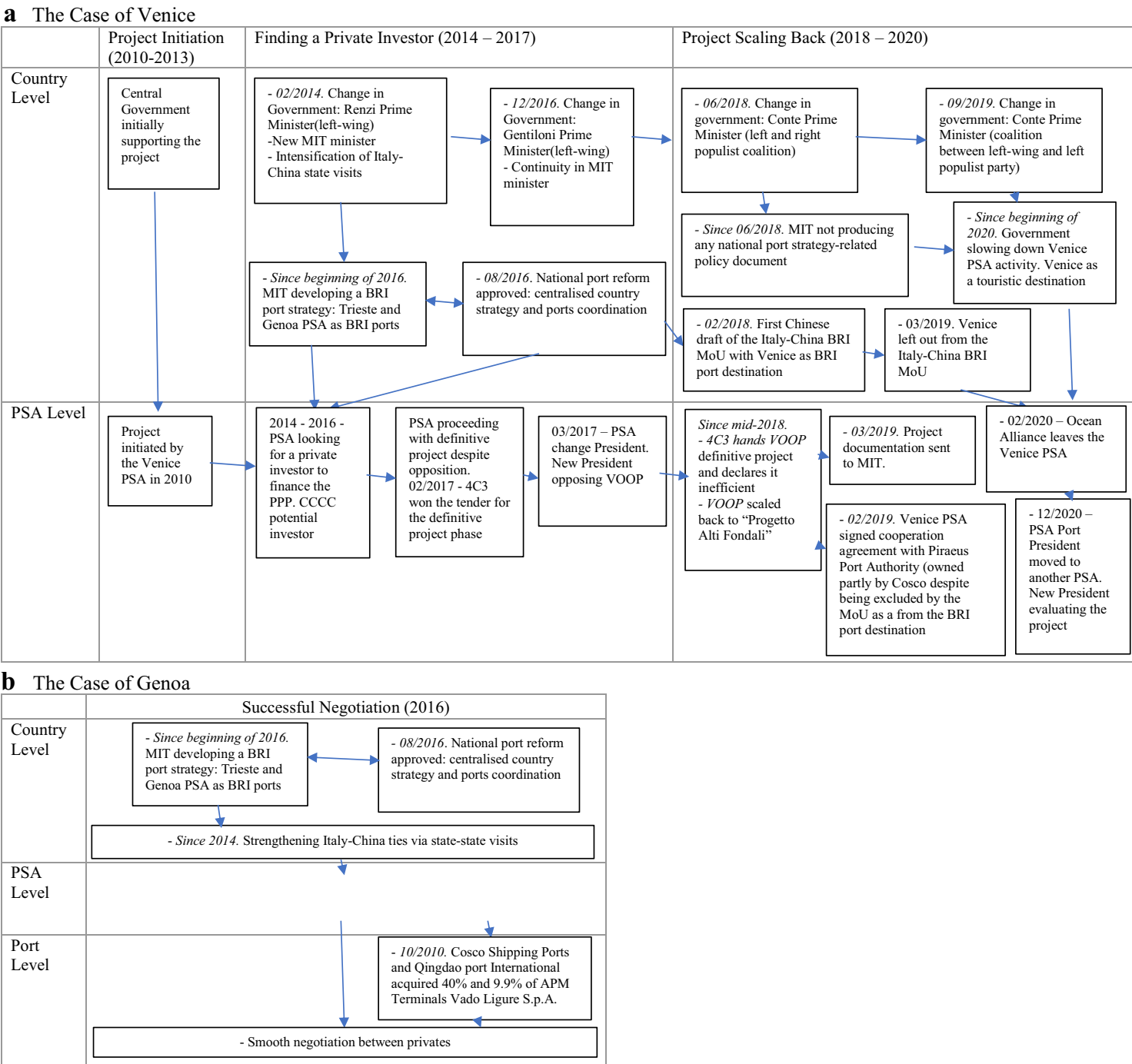

Figure 2 Timeline of multi-level bargaining. a The Case of Venice. Source Authors. b The Case of Genoa. Source Authors. c The Case of Trieste. Source: Authors. d The Case of Taranto. Source Authors.

interviews between September 2019 and March 2021. Interviewees were identified and approached through convenience and snowball sampling. Potential interviewees were approached via e-mail to introduce them to the project and share with them the participant information sheet. Once an interview was secured and scheduled, it was conducted in-person (16 interviews) or via Zoom videoconferencing due to COVID-19 restrictions (30 interviews). Scholars have recently shown the effectiveness of videoconferencing, especially Zoom, as a means for carrying out interviews (Archibald, Ambagtsheer, Casey, \& Lawless, 2019).
All interviews were recorded and transcribed. When interviews were held in Italian, two of the authors, who are both native speakers, translated and double-checked the interviews. Transcripts were anonymized and identifiers as well as the original audio recording deleted in accordance with the research ethics guidelines of the University of Leeds. ${ }^{3}$

The analysis of a process study is based on events and temporal patterns (Langley, 1999). We firstly compiled the stories of the various investments which were discussed with interviewees. Once the histories of the various cases were ready, we traced the main critical events at the three levels of 
c The Case of Trieste

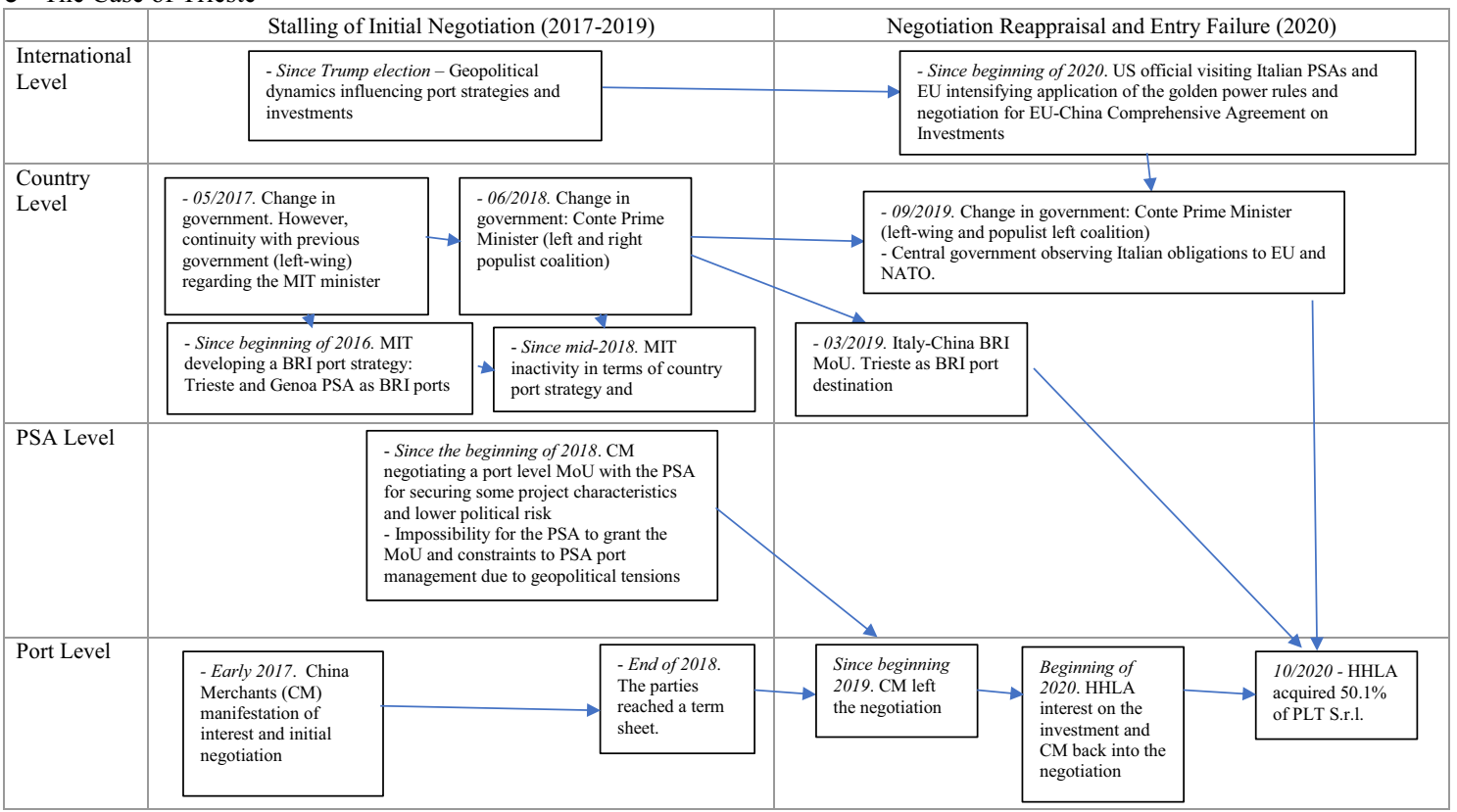

d The Case of Taranto

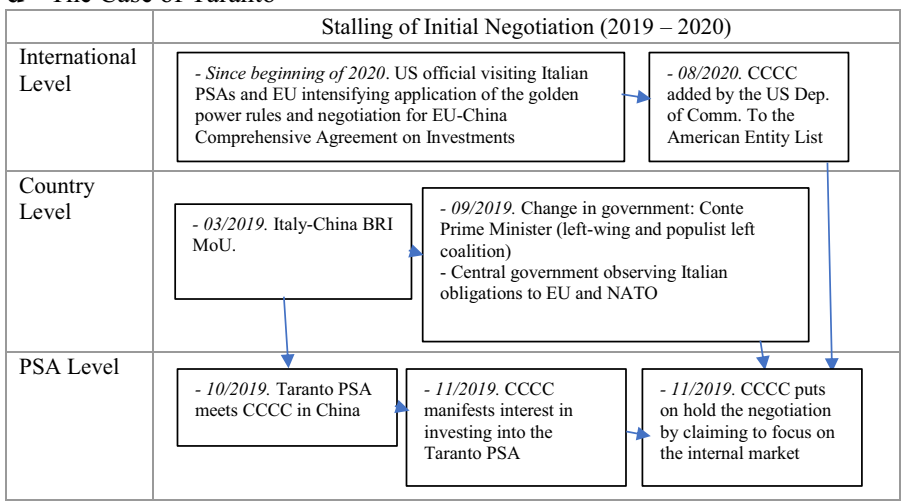

Figure 2 continued

Table 2 Data sources

\begin{tabular}{|c|c|c|c|c|c|}
\hline & Venice & Genoa & Trieste & Taranto & External \\
\hline $\begin{array}{l}\text { Number } \\
\text { of } \\
\text { interviews }\end{array}$ & $\begin{array}{l}11 \text { (6 Via video } \\
\text { conferencing) }\end{array}$ & $\begin{array}{l}12 \text { (8 Via video } \\
\text { conferencing) }\end{array}$ & $\begin{array}{l}8 \text { (4 Via video } \\
\text { conferencing) }\end{array}$ & $\begin{array}{l}5 \text { (All via } \\
\text { video } \\
\text { conferencing }\end{array}$ & 10 (7 Via video conferencing) \\
\hline $\begin{array}{l}\text { Total } \\
\text { length } \\
\text { (min) }\end{array}$ & 820 & 900 & 460 & 370 & 890 \\
\hline $\begin{array}{l}\text { Type of } \\
\text { actors }\end{array}$ & $\begin{array}{l}\text { Ex- and current port } \\
\text { officials, competitor } \\
\text { container terminals, } \\
\text { industrial representative }\end{array}$ & $\begin{array}{l}\text { Ex- and current port officials, } \\
\text { competitor container } \\
\text { terminals, labor unions, } \\
\text { industrial representative }\end{array}$ & $\begin{array}{l}\text { Current port } \\
\text { officials }\end{array}$ & $\begin{array}{l}\text { Current port } \\
\text { officials and } \\
\text { local unions }\end{array}$ & $\begin{array}{l}\text { Italian and international port } \\
\text { and consultants, Italian } \\
\text { maritime lawyers, other Italian } \\
\text { port authorities' officials }\end{array}$ \\
\hline
\end{tabular}

Source Authors. 
analysis. We accordingly tried to understand how the various actors at the different levels of analysis were able to protect or capture property rights over assets and how the implementation of the BRI affected the various efforts.

\section{FINDINGS}

\section{The Case of Venice}

\section{Project initiation (2010-2013)}

PSA level. The Venice Onshore Offshore Platform (VOOP) was conceived and initiated by the Venice PSA around the end of 2009 and the beginning of 2010. The Port of Venice and its location in the North Adriatic Sea were seen by local agents as strategic for the entrance of goods from East Asia into the Central European market. In particular, the development of the VOOP could save five navigation days compared to Northern European ports (e.g., Antwerp and Rotterdam). The project was conceived to enable the Port of Venice to host large container carriers and compete with Northern European ports.

\section{Finding a private investor (2014-2017)}

PSA level. The focus of the Venice PSA was on finding a private investor which would partially finance the new infrastructure. The central government would have financed the structure with a contribution of around $€ 1$ billion on the condition that a private investor would cover for the remaining sum (Port of Venice, 2014). The project was endorsed by the Italian government and included as a "to-be prioritized infrastructure" in the national economic policy document (Documento di Economia e Finanza) of 2013. At the end of 2014, the preliminary project was approved by the Veneto region ${ }^{4}$ and the Ministry of Environment. However, according to an ex official of the Venice PSA:

When at the end of 2014 we went to Singapore to understand whether Port Singapore Authority, that was already operating in our port, was interested in being the potential private promoter of the project financing, we were only assisted by the Ministry of Foreign Affair and not by the Ministry of Infrastructure and Transportation. This was clearly showing that the central government was not interested in the project (Field Notes, August, 2020).
The de jure procedure for infrastructure projects required the MIT to send the preliminary project within 180 days to the Italian Economic Planning Committee (CIPE) for final approval to start the definitive project phase before construction. Despite the fact that MIT was delaying the transmission of the project to CIPE, in May 2015, the then-President of the Port of Venice, Paolo Costa, released an interview announcing that, CCCC - a Chinese SOE world leader in transportation infrastructure, dredging, and heavy machinery manufacturing business - would finance the project (Quarati, 2015). According to an ex-official of the Venice PSA: "They [CCCC] did not have any problem in becoming the private part of the project financing. They told us that they had $€ 60$ bn of investment around the world and it would not have been a problem to finance the project" (Field notes, October, 2020).

However, the problem for the Venice PSA was that of convincing the MIT about the importance of the project to then proceed with the de jure passages to reach the definitive project phase. By August 2016, the preliminary project was still with the MIT, exceeding the typical evaluation period by 18 months. The Venice PSA sent an official request (parliamentary interrogation - no. 3-03080) to the MIT to investigate why the timeline was not being observed. According to the interrogation, this practice was increasing the investment risk and preventing potential investors from taking part in the PPP. Regardless of the MIT's inaction, the Venice PSA decided to carry on with the tender for the definitive project, which can still be put through despite that the preliminary project was not yet approved by CIPE - essential to start the construction phase, however. The Consortium 4C3, composed of two small Italian engineering firms and CCCC, won in September 2016 the bid for the execution of the definitive project and signed a contract worth $€ 4$ million in February 2017. In March 2017, however, the president of the Venice PSA changed and the VOOP was opposed by the new president (Antico, 2017).

National level. At the national level, the introduction of the VOOP was opposed by competing Italian ports and regional politicians. The Venice PSA was facing competition, in particular, from the Trieste PSA and the Friuli-Venezia Giulia region, ${ }^{5}$ located like the Venice PSA in the North Adriatic 
Sea, and from the North Tyrrhenian port system. Trieste PSA and the regional and local government of the Friuli-Venezia Giulia region openly opposed VOOP. The then-president of the Friuli-Venezia Giulia region, Debora Serracchiani, stated in an interview: "I see it [the VOOP] not only as a pharaonic project, but also very useless as far as the North Adriatic port dynamics are concerned" (Il Gazzettino, October 2014). The competition with the Tyrrhenian port system was expressed via the main industrial association. An ex-official of the port of Venice told us: "The Italian Port System was mainly born in the Liguria region and especially in Genoa. Key people in Rome are often from the area. They have a say in what happens and they have been taking care of the sector since its inception. The North Adriatic cannot be ahead of Genoa" (Field notes, August, 2020).

In December 2016, Gentiloni replaced Renzi as Prime Minister of Italy and became the fourth Prime Minister in the space of 5 years. Yet, the MIT minister remained in place. This led to continuity in the decision not to finance the VOOP and to the creation of a BRI country strategy with Trieste and Genoa PSAs as BRI port investment destinations. Regarding BRI, the then-MIT President Graziano Delrio declared: "Our port of Genoa and Trieste are ready" (Il Piccolo, citing Graziano Del Rio, March 2017). The BRI strategy was being developed within a broader national port governance reform (law decree, 169/2016) which entered into force in August 2016 and which centralized the coordination of the PSAs' activities and fostered by increasing Italy-China relationships (Fardella \& Prodi, 2017). Despite that the Chinese were signaling Venice as the arrival terminal of the BRI, the thenMIT president highlighted how this was only a historical inheritance and that "the Italian port system must be seen as one. The port reform had this aim: reunite all PSAs under a unique central direction" (ANSA, 2017).

The case illustrates how the de jure rights ${ }^{6}$ the PSA had over the development of the infrastructure did not represent the totality of rights to be protected. Italian competing ports were indeed able to oppose the project via political activity. At the same time, the MIT itself was using its power position demanded by the central government by not respecting the de jure infrastructure assets procedure. The Venice PSA was in fact spending resources by trying to protect its rights through the parliamentary interrogation besides those that the country had spent for the different phases of the project. The objective of the 2016 governance reform was exactly that of coordinating port activities by reducing, among others, the number of PSAs from 24 to 15 for better coordination.

\section{The Venice PSA taken out of the Italy-China MoU (2018-2020)}

PSA level. Besides the opposition of the VOOP by the new president of the Venice PSA, in May 2018, 4C3 declared VOOP as inefficient due to weather conditions. In parallel, CCCC presented to the Venice PSA a preliminary project for the "Progetto Alti Fondali" - the project would bring the off-shore part just outside the lagune to avoid cargo disruption - which was requested by the new president. Besides, in November 2018, the Venice PSA drew up an agreement with Cosco Shipping for a new container line connecting Venice to the Piraeus port and a commercial MoU with the Piraeus Port in February 2019 to strengthen the relations and cargo flows between the two ports. Despite that the documentation for the new project was sent to the MIT in the middle of 2019, the Venice PSA started having problems with the central government regarding the excavation of the port seabed. In fact, in January 2020, a direct line between Asia and Venice was cancelled ${ }^{7}$ because of the port accessibility. A local politician of the Venice municipality pointed out that:

the Partito Democratico ${ }^{8}$ and the Five Star Movement want to focus on the City, but in reality, they behave differently ... A proactive government would help the local authorities to make the Venice industrial area and the port to take off, instead every month they hinder the undertaking of activities required for us to compete (Trevisan, 2020).

National level. The central government not only excluded Venice as a final BRI destination but they also had a clear industrial strategy which would make Venice more active in tourism instead of industrial activities such as new container terminals. At the end of 2020, the president of the Venice PSA was moved to another PSA, and the new president is now evaluating what to do with "Progetto Alti Fondali". From an interview with an ex-official of the Port of Venice, we were told that: "when in February 2018 the Chinese sent to the central government the first draft of the Italy-China $M o U$, the Chinese put Venice as one of the BRI port investment destinations" (Field notes, August, 2020). However, the Italian central government was able to follow its strategy, and in March 2019 only the Trieste and Genoa PSAs were included within the Italy-China MoU. 


\section{The Case of Genoa}

\section{Successful negotiation (2016)}

In parallel to the scaling back of the VOOP project, Cosco Shipping Ports and Qingdao Port International acquired 40 and 9.9\%, respectively, of the APM Terminals Vado Ligure S.p.A. (APM) within the Vado Ligure Port ${ }^{9}$ in October 2016. APM is the joint venture that has designed, and is currently building, the Vado Gateway container terminal. When Cosco and Qingdao partially acquired APM, the project was already under construction.

PSA level. Since the beginning of 2016, the Italian government had been implementing the port national reform and reforming its port strategy, which entered into force in September 2016. Unlike other PSAs, which were unified immediately, Savona and Genoa were integrated in January 2017. When Cosco and Qingdao invested in 2016, they asked senior managers of the Savona PSA for reassurances that the administration of the port would remain the same, denoting a particular concern with the political uncertainty in Italy. The Italian port rules require communication of new shareholder arrangement for an existing concession holder to the PSA. The acquisition by Cosco and Qingdao was anticipated by a period of meetings between the private investors and the PSA. These talks started around the beginning of 2016, according to an ex senior manager of Savona PSA:

\footnotetext{
There was not really a negotiation with us. We went to China and they came here several times. They were clear regarding their objectives. What they asked were assurances regarding the timeline of the construction of the project. After what had happened in Naples ${ }^{10}$, they wanted to be sure about the feasibility of the investment. They were worried about the "contamination" of the Italian politics (ex-official of the Port of Savona, Field notes, May, 2020).
}

Meetings were held at Assoporti - an Italian Port representative association - in which the thenpresident of the Savona PA had the opportunity to exchange opinions with other PSA presidents regarding the strategic intent of the new investors. The project financing contract was the only contractual relationship present between the Savona PSA and APM when Cosco and Qingdao acquired APM. One manager of the Genoa PSA pointed out that: "the project financing contract related to the design and construction of the terminal was not altered when the two companies joined the project" (Field notes, April, 2020).
National level. The smooth acquisition was accompanied by a political environment characterized by strengthening ties between China and Italy through state visits and by a coordinated national port strategy which declared Genoa and Trieste as the BRI investment locations. The BRI was not yet the primary focus of the central government. Prime Minister Renzi said in an interview with Chinese media in September 2016:

\begin{abstract}
I believe we have a lot of possibilities are we to follow the One Belt One Road Initiative, but in my mind the priority is the decision reached by the Italian government regarding the Port regulation: this is a great opportunity, as Italy is a country bathed by the sea and the conclusion of the road between China and Europe could well be the Italian ports (Il Sole 24 Ore, 2016).
\end{abstract}

\section{The Trieste Case}

\section{Stalling of initial negotiation (2017-2019)}

The interest of China Merchants Holdings (CM) in acquiring the Piattaforma Logistica S.r.l. (PLT) - an Italian local company which was constructing a multi-purpose terminal within the Trieste PSA started in 2016 and materialized soon after with a manifestation of interest by CM. The negotiation started in 2017 and went on for two full years until the end of 2018.

Port level. When the negotiation between the CM and PLT started, PLT was still completing the construction of the terminal. According to a senior manager of PLT: "They were worried about the likelihood that the project would be finished on time due to the Italian institutional system. We reached a term sheet at the end of 2018, but they then disappeared for the entire 2019" (Field Notes, February, 2021). CM did not want to complete the acquisition until construction would be completed and was not willing to give assurances about further developing the infrastructure. PLT was looking for an investor which would not only enter while the terminal was still under construction, but which would be also interested in further developing the infrastructure after its completion. The terminal under construction was in fact the base for a further investment that the local owners and the Trieste PSA were keen to develop. According to a senior manager of PLT:

We did not negotiate the hypothesis of further developing the infrastructure, but it was clear that it was an important aspect to consider for PLT in selecting the investor. Yet, they left the negotiation most likely to let us reach the closure of the construction. It would have been difficult for us to be guaranteed on the future development of the infrastructure (Field Notes, February, 2021). 
PSA level. The construction of the terminal was governed by a PPP contract with the PSA which states the various stages of the construction process and assign specific rights of control to the various actors. CM perceptions was that of impossibility of safely controlling all the rights over the terminal for instance the possibility of using the terminal at a certain date. Hence, although the PPP contract would legally protect the investor, CM's expectation of using the asset was affected by the perception that the Italian political environment would influence the control over the terminal. To better manage the economic rights over the infrastructure (e.g., the possibility for $\mathrm{CM}$ to have a certain starting date for the terminal operations), CM did negotiate with the PSA about the possibility of bringing the investment under a MoU. However, this was not possible for the PSA. On the contrary, the PSA's president did involve the central government into the negotiation [i.e., the MIT and the Ministry of Foreign Affair (MFA)]. According to an official from the Trieste PSA:

\begin{abstract}
When they are required to abide by the rules, they might get cold. They believed that any informal agreement would be binding and that because in China they are considered as public entity, they should be treated as such when they invest abroad. We, however, use public tenders for any type of investor (Filed notes, August, 2020).
\end{abstract}

National level. As mentioned within the Genoa case, Trieste and Genoa PSAs were chosen by the Italian central government as the BRI investment location. Under the Gentiloni government in early 2018, the first draft of the Italy and China MoU was drafted by China and CCCC was the main investor in the agreement for the proposed investments within the Genoa and Trieste PSAs. This further accounts for the arrival of CCCC at the port of Trieste and the potential stall of the negotiation between CM and PLT. According to an official of the Trieste PSA: "when we told CCCC that CM was already negotiating with PLT for the terminal, they completely changed their attitude. They were clearly unaware of that. Besides the worry about the project timeline, the hierarchy between Chinese MNEs within BRI might have played a role" (Filed notes, August, 2020).

Negotiation reappraisal and entry failure (2020)

Port level. The pre-agreement signed between PLT and CM expired in 2019, which led PLT to accept other manifestation of interests. Among these, PLT received that of Hamburger Hafen und Logistik AG
(HHLA) - a German MNE specialized in container logistics. In 2020, China Merchants discovered the existence of the negotiations with HHLA. According to PLT's senior manager: "we told them that the pre-agreement could not be considered valid and that conditions can now change as we have more interests on the infrastructure" (Field Notes, February, 2021). Despite the counteroffer made by CM, in September 2020 PLT chose HHLA as the investor. PLT justified the choice as follows: "CM has always had a pure business interest. Politics never played a role for $C M$ over the negotiation. Politics came in later. Unfortunately, the fact that we had to get approval from the central government via the Golden Power rule played a role in choosing HHLA" (Field Notes, February, 2021).

National level. In June 2018, the populist coalition of the Five Star Movement and La Lega came into power and led Italy to the signing in March 2019 of the Italy-China BRI MoU. According to the then-Italian Prime Minister Giuseppe Conte, the MoU: "is purely an economic agreement which does not create any de jure obligation and it is perfectly aligned to the EU strategy" (Buzzanca, 2019). However, when in October 2020 HHLA acquired 50.1\% of PLT, in an interview to an Italian newspaper, the Ministry of Economic Development declared that: "Having the Chinese as investor could have brought some preoccupations and worried our American allies" (Arnese \& Whalsingham, 2020). In September 2019, the central government changed again, and the main Italian center-left party (Partito Democratico) replaced La Lega and formed a coalition with the Five Star Movement. This further change in the lead of the central government brought Italy back into its EU and NATO obligations. On this issue, from an interview we had with an official from the port of Trieste more than 1 year after the signing of the MoU, we were told that: "the MoU is an empty document but very important in its meaning. The signing of the MoU is clearly inserting an amount of politics into port investments and has brought a much higher attention from US and EU regarding what we do" (Field Notes, August 2020). It would have been difficult for the Italian government to unilaterally enforce the rights over its infrastructures (i.e., port terminals) by means of the Golden Power rule. The Golden Power (special power) rule, which was issued by the European Parliament and the European Counsel and endorsed by EU countries, gives the Italian central government the possibility (special power) to veto the acquisition of strategic assets of national importance by foreign investors. Whereas before 2020 the rule could only be applied 
to extra EU companies, since 2020 the Italian government has adopted (law-decrete no. 23 April, 2020) the European Commission's communication $(26 / 03 / 2020)$ to extend the application of the rule to intra-EU FDI. However, according to PLT's president, unlike in the case of HHLA, the potential entrant of $\mathrm{CM}$ could have been blocked by the central government. In this phase of the negotiation, PLT's rights to transfer the asset have been influenced by the fact that rights to the terminal could have been captured by the Italian central government via the application of the "Golden Power" rule.

\section{The Case of Taranto}

\section{Stalling of initial negotiations (2019-2020)}

PSA level. CCCC's interest in realizing a new container terminal and a logistic area within the Taranto port started in the middle of 2019. Unlike Genoa and Trieste, the Taranto PSA was not included in the BRI MoU that Italy and China signed in March 2019. Meetings between CCCC and the port started in China when Intesa Sanpaolo, an Italian bank, organized a mission in October 2019 to promote Italian Special Economic Zones to potential Chinese investors. According to a Taranto's PSA official: "we both presented our organizations and very shortly after the mission we received the manifestation of interest from CCCC" (Field notes, September, 2020).

National level. In November 2019, the Taranto PSA forwarded CCCC's expression of interest to the central government where the MFAs and International Cooperation had created a "control room" to manage relationships with foreign investors in the middle of 2017. The PSA met CCCC in Rome together with the Italian Prime Minister, the MFA and International Cooperation, and the MIT. According to a Taranto PSA official: "at the reunion in Rome, there were also industrial representatives, and other public and private representative associations, which favored the exchange of opinions about the investment" (Field Notes, September, 2020). CCCC had to prepare some propositions for the PSA and the Italian government that highlighted the economic value of their proposed project to the country. An official from the Taranto PSA highlighted that: "we made clear to them since the beginning that we were not interested to build white elephants but we were looking for someone interested to manage the infrastructure. CCCC could bring low value added under this view" (Field Notes, August, 2020).
CCCC was having difficulties in finding a partner interested in managing the infrastructure: "Cosco and China Merchants could have been interesting partners, yet it seems they were not aligned in their intentions" (Taranto PSA port Official, Field Notes, September, 2020). According to an official of the Taranto PSA: "In the last video call we had with them, we have been told that, despite they have an interest in the port, they have decided to dedicate themselves to the internal market and to stop foreign investments" (Field Notes, August, 2020).

International level. Our initial conceptualization focused on a three-layered governance structure. Yet, the Case of Trieste challenges this perspective and indicates how geopolitics plays an important role. Divergent political and economic interests within Italy and the EU, and with the USA have been highlighted by an official of the Taranto PSA:

\begin{abstract}
We know CCCC elaborated a document, but due to lockdown [Covid-19-related lockdown] it was never sent officially. Yet, we also know the US has been a problem, as CCCC was added at the end of August 2020 [Wed 26/08] by the US Department of Commerce to the American Entity List. The Americans are paying visits to the majority of Italian ports.
\end{abstract}

The rights of the Taranto PSA and potential investors seems to have been influenced by geopolitical maneuvers. Besides the US activities, the EU intensified the negotiation of the EU-China Comprehensive Agreement on Investment (an agreement was reached in December 2020 and awaits ratification) in order to give the $\mathrm{EU}$ a unique voice in negotiations with China.

\section{DISCUSSION AND CONCLUSION}

We began by asking how the multi-actor and multilevel bargaining process over Chinese MNEs entry is influenced by the implementation of the BRI in the host country. To answer this question, we brought together bargaining theory (Vernon, 1971) and property rights theory (Barzel, 1997; Coase, 1960). Unlike bargaining theory, which adopts a legalistic definition of ownership where the rights the owner has over an asset are well defined and perfectly enforced, the property rights perspective adds the concept of economic property rights. Rights to an asset are not perfectly defined and enforced and can be captured by various actors of the port system. By building upon this theoretical framework, this article developed a bargaining processual perspective made up of the capture and protection efforts 
of the actors of the port system. Further, we showed how the institutional, political, and geopolitical environment influence the ability of actors to capture and protect their rights. Our paper adds concrete detail to those areas that entrants are vaguely adjured to investigate before initiating the foreign investment process. We enable a rounded understanding of the institutional and bargaining framework that the parties need to negotiate in order to achieve a satisfactory mutual outcome.

The Case of Genoa represents the only successful entry for Chinese MNEs within the Italian port system since the BRI was launched. The entry was made possible thanks to the absence of rights capture attempts by the existing actors of the port system during the bargaining process. At the port level, the existing terminal operator was able to smoothly transfer the rights of the existing terminal company whose main asset was the container terminal under construction. At the time of entry, the PPP contract between APM Terminals S.p.A., the Savona PSA, and the central government was unaltered, delineating a perceived ability by the investor but also by the other actors of the system to proceed smoothly with the construction of the infrastructure. The initial perceived risk by the Chinese investor was mitigated by the promotion activity of the PSA. The ability of the various parties to control the rights was favored by a country-level political environment that was aligned in terms of having the Genoa PSA as a BRI port investment destination.

Our three other cases represent instances of failed negotiations. The Case of Venice sheds light on the difficulty that the Venice PSA faced in developing a new infrastructure and for CCCC to become the investor. The rights of the Venice PSA to promote a new infrastructure were captured initially by the effort of competing ports and subsequently by the MIT and Italy's BRI strategy, which declared the Trieste and Genoa PSAs as main BRI ports. The effort by the Chinese government to influence the integration of the Venice PSA within the ItalyChina MoU was resisted by the Italian central government, which seems to be reorienting the industrial strategy behind the activities of the Venice PSA. The Cases of Trieste and Taranto highlight the influence of the country's political environment. Initially, and in line with the Case of Genoa, the bargaining dynamics of the Case of Trieste highlights the difficulty for China Merchants in perceiving the ability to secure the rights over the infrastructure. However, after the signing of the BRI MoU, the difficulties for both PLT and China Merchants to successfully close the negotiation were represented by the capture activity of the central government through the implementation of the Golden Power rule. The return of Partito Democratico (left-wing) in the government coalition brought Italy closer to EU and US interests. Table 3 provides a comparison of the four cases and highlights the main critical events that have led to the negotiation outcome.

\section{Contributions to Theory}

Our first contribution is to bargaining power theory. In particular, we developed a processual multiactor and multi-level perspective that accounts for the different mechanisms of capture and protection of resources by the different actors engaging into the bargaining process over MNE entry. Our results show that Chinese MNEs initially led their negotiations and engaged with actors at different governance levels, which led to successful acquisition in the Case of Genoa where rights between parties where well delineated. However, the signing of the Italy-China BRI MoU, and hence the intervention of the Chinese government ex post, has brought geopolitical pressure over the projects, leading to failed acquisitions or stalling negotiations. Secondly, we showed how the institutional, political, and geopolitical environment matters in enabling and constraining the resource protection and capture activities of the various actors.

Additionally, we contribute to the emerging market multinationals (EMNEs) literature and in particular on the importance of the host-country institutional environment, and we respond to recent calls for thicker descriptions and grounded research on Chinese MNEs' internationalization (Ramamurti \& Hillemann, 2018). Scholars have looked at the role of home-country policies on the pattern of EMNEs internationalization (e.g., Luo, Xue, \& Han, 2010), however, the case of the implementation of a home-country policy in the host country and its influence on the foreign market entry activities of its MNEs is underexplored. Accordingly, we showed how in the case of Italy the implementation of the BRI policy, and its culmination into a MoU, did not favor the entry of Chinese MNEs. Finally, we contribute to the larger BRI literature that to date takes a Chinese government- and/or business-centric approach (Gong, 2019; Sutherland et al., 2020; Yu, 2017) by also investigating Chinese government objectives (Summers, 2016; Tekdal, 2018) and showing how the 
Table 3 Case study comparison

\begin{tabular}{|c|c|c|c|c|}
\hline & The Case of Venice & The Case of Genoa & The Case of Trieste & The case of Taranto \\
\hline $\begin{array}{l}\text { Type of } \\
\text { investment }\end{array}$ & $\begin{array}{l}\text { New PPP (Design-Build- } \\
\text { Finance-Operate (DBFO) } \\
\text { to build a new container } \\
\text { terminal. Initiated by the } \\
\text { Venice PSA, which } \\
\text { individuated CCCC as the } \\
\text { potential private investor }\end{array}$ & $\begin{array}{l}\text { Potential entry into an } \\
\text { existing PPP. Ongoing } \\
\text { construction of a container } \\
\text { terminal in the port of } \\
\text { Vado Ligure followed by a } \\
50 \text {-year concession } \\
\text { contract upon project } \\
\text { finalization (M\&A) }\end{array}$ & $\begin{array}{l}\text { Potential entry into an } \\
\text { existing concession. } \\
\text { Ongoing construction of a } \\
\text { multi-purpose terminal. } \\
(M \& A)\end{array}$ & $\begin{array}{l}\text { Potential construction of a } \\
\text { new container terminal or } \\
\text { logistic area }\end{array}$ \\
\hline Chinese & $\mathrm{CCCC}$ as potential private & Cosco Shipping Ports and & China Merchants Group & $\mathrm{CCCC}$ \\
\hline
\end{tabular}

investor

Negotiation

investor for the PPP

time frame

2010-2020

Port level

No data

PSA level

National level

Negotiation between PSA and Italian central government. PSA seeking private investor

Qingdao Port International 2015-2016

and CCCC

2017-2020

2019-2020

Smooth transfer of rights between parties

Private negotiation influenced by investor perception of political risk over rights appropriation PSA unable to directly deal with Chinese investor perceived risk by Chinese investor via informal state visits

International and geopolitical level

Outcome
Genoa declared by the central government as a final BRI destination, stable political environment over the negotiation period MoU, national political instability over the negotiation period
Geopolitics not yet influencing port investments
Geopolitics not yet influencing port investments
Trieste declared by the central government as a final BRI destination, national political instability over the negotiation period, inability of central government to freely enforce golden power rule over the investment, ItalyChina MoU brought instability

Geopolitics started influencing port investments - US officials visiting Italian ports, New FDI regulation (March 2019) by EU and acceleration of EU-China Comprehensive Agreement on Investments

Failed entry. Hamburger Failed project approval by the Italian central government. Project stalling since the beginning of 2016. Venice port excluded from ItalyChina BRI MoU
Successful entry in October 2016. Cosco Shipping Ports and Qingdao Port International acquired 49 and $9.9 \%$, respectively, of the equity that A.P. MollerMaersk held in APM Terminals Vado Ligure S.p.A.
No data

Negotiation between PSA and Chinese MNE

No change in central government over the negotiation period, but different government from the one which signed the Italy-China MoU in March 2019, Italy-China MoU indirectly influenced the negotiation

Geopolitics started influencing port investments - US officials visiting Italian ports and CCCC added by US Department of Commerce to the America Entity List, New FDI regulation (March 2019) by EU and acceleration of EU-China Comprehensive Agreement on Investments Negotiation stalling after manifestation of interest since. CCCC communicated to the Taranto PSA the interest of temporarily focusing on the internal market

Source Author. 
implementation of the BRI in the host country seems to be a trial-and-error process.

\section{Policy Implications}

Our paper has several IB policy implications for host-country policy makers. Our results point to the need to be cognizant about the allocation of rights at different governance levels to facilitate the allocation of infrastructures. In particular, policy makers should pay particular attention to the various capture activities that might lead to failure to allocate infrastructures or to allocate them to actors that have goals diverging from that of the host country. The internalization process of externalities must hence account for the various actors at multiple levels. The same government or agencies (e.g., PSAs) need to be aware of the ways they implement their policies to avoid capturing rights over assets that would lead to worsening the initial perception of investors and the allocation of effective control over rights that would be required for the investment to happen. In order to attain optimal policies, host-country public bodies need to understand the (international) opportunities facing them to improve the port nexus and to skew it for their benefit.

Two of the four cases (i.e., Trieste and Genoa) are instances of acquisitions of companies involved in PPPs for building and managing the infrastructure. In both cases, our data suggest that the investors were skeptical about the timeline of the project due to the perception of potential capture activities that, in the Case of Trieste, led to the stalling of the negotiation. Policy makers should try to create mechanisms that would enable potential investors to better understand the status and fluidity of local property rights arrangements.

The second part of the negotiation, in the Case of Trieste, has been characterized by the difficulty of the host-country terminal owner to understand how the central government would have applied the Golden Power rule had the Chinese investor been chosen. Accordingly, it is important that FDI screening and sanctioning policies are clear in how they evaluate potential investors. This would be of help in promoting continuity over policy application in the instance of frequent changes in government.

The Cases of Venice and Taranto illustrate the challenges investors face when initiating new infrastructure investments. In the Case of Venice, the PSA led the initiation of the investment project and was looking for an investor. The unclear alignment in strategy between the central government and the PSA led the MIT in capturing rights by not applying the legal rules about the steps for project approval. Policy makers should be aware of the waste of resources that a missing coordination between the center and the local PSA can cause. At the end of 2016, Italy did in fact reform its governance system by promoting more central coordination through a conference of PSAs' presidents that would coordinate the activities and investments of the various PSAs.

From our cases, we also derive specific BRI policy implications for host countries and China. In particular, the relevance of a coordinated approach between PSAs' investments would lower ports competition over Chinese investments. The strategy should be internalized by several PSAs to avoid single PSAs pursuing their interests by interfering with each other's investment opportunities or pursuing investments that have little strategic sense in a wider port country strategy. Having a clear port strategy would also avoid third countries capturing activities over port investments.

Our cases also show that Chinese MNEs seem to lack a coordinated approach on their investment activities under the BRI framework and the need to better understand a potential hierarchy among Chinese MNEs. The fact that CCCC was the main port investors declared in the Italy-China MoU lead to think that Chinese SOEs might act differently when negotiating investments under the BRI policy framework. Finally, our cases show how, despite its non-binding nature, MoUs might increase geopolitical pressure over signatory countries. China should hence understand better the context in which they use this capture means.

\section{Boundary Conditions and Suggestions for Future Research}

The cases of Chinese MNEs entry into the Italian port system under the BRI policy framework allowed us to show how the bargaining process around foreign entry can be explained by property rights capture and protection activities of the various actors at different governance levels. Although the context of the Italian port system is idiosyncratic, we believe the results can be transferred to other contexts. In particular, the emerging country institutional environment in which the majority of the bargaining literature is developed could provide interesting perspectives into both the allocation of rights and the capture and protection strategies used by the various actors. 
The importance of the institutional and political environment underlying the implementation of BRI with MNE foreign entry should be developed in future research. Our study does not establish theoretical connections between the evolution of the geopolitical environment and the implementation of BRI through FDI in host countries and this provides an excellent research agenda.

\section{NOTES}

${ }^{1}$ The legislative decree 169/2016 has substituted the law 84/1994.

${ }^{2}$ Before the 2016 Italian Port Reform, the port of Vado Ligure was under the jurisdiction of the Savona Port Authority. In 2016, the latter's jurisdiction has passed to the Genoa Port System Authority.

${ }^{3}$ The research project was approved (approval code: AREA 19-033) by the University of Leeds Environment and Social Sciences Joint Faculty Research Ethics Committee.

${ }^{4}$ Venice is the flag town of the Veneto region.

${ }^{5}$ Trieste is the capital of the Friuli-Venezia Giulia region.

${ }^{6}$ Before the 2016 national port governance reform, the de jure rights were contained by the law no. 84/1994.

\section{REFERENCES}

Alchian, A. A. 1965. Some economics of property rights. II Politico, 30(4): 816-829.

Antico. 2017. Musolino: "Porto offshore? Riportiamo I'astronave sulla Terra...". The Medi Telegraph. https://www. themeditelegraph.com/it/transport/ports/2017/06/28/news/ musolino-porto-offshore-riportiamo-l-astronave-sulla-terraintervista-1.38156662. Accessed 20 September 2020.

ANSA. 2017. Porti: Delrio, nessuna discriminazione per la 'via della seta', il sistema è unico. https://www.ansa.it/mare/notizie/ portielogistica/news/2017/05/17/portidelrionessunadiscriminazionevia-setasistema-unico_6c10979b-e07d-4776b247-3c166e9bd6b8.html. Accessed 20 September 2020.

Archibald, M. M., Ambagtsheer, R. C., Casey, M. G., \& Lawless, M. 2019. Using Zoom videoconferencing for qualitative data collection: Perceptions and experiences of researchers and participants. International Journal of Qualitative Methods, 18: $1-8$.

Arnese and Whalsingham. 2020. Hhla, tutto sulla società pubblica tedesca che controllerà il porto di Trieste. Start Magazine. https://www.startmag.it/smartcity/hhla-tutto-sullasocieta-pubblica-tedesca-che-controllera-il-porto-di-trieste/. Accessed 20 November 2020.

Bartlett, L., \& Vavrus, F. 2016. Rethinking case study research: A comparative approach. New York: Routledge.

Barzel, Y. 1997. Economic analysis of property rights. Cambridge: Cambridge University Press.

Barzel, Y. 2015. What are 'property rights', and why do they matter? A comment on Hodgson's article. Journal of Institutional Economics, 11(4): 719-723.
${ }^{7}$ The Ocean Alliance - one of the three main container liner alliances of the maritime industry made by Cma Cgm, Cosco Shipping Lines, Evergreen Line e Oocl - had a constant liner service between Venice and Asia.

${ }^{8}$ In September 2019, the central government changed. The Partito Democratico replaced La Lega in the leading coalition with the Five Star Movement.

${ }^{9}$ The Port of Vado Ligure was allocated under the jurisdiction of the Genoa PSA during the 2016 reform. Previously, it had been managed and controlled by the Port of Savona.

${ }^{10}$ In 2000, Cosco Shipping Ports acquired in a JV with MSC $50 \%$ of Conateco S.p.A. - a local terminal container company. The JV agreed with the thenNaples PSA to further develop the terminal. In 2015, Cosco left Naples and to date the terminal development is still ongoing.

\section{ACKNOWLEDGEMENTS}

The authors are thankful to the North Adriatic Sea Port Authority (Port of Venice: Italy) for their financial support (Protocol Procedure n11765 rep 206).

Beeson, M. 2018. Geoeconomics with Chinese characteristics: The BRI and China's evolving grand strategy. Economic and Political Studies, 6(3): 240-256.

Benito, G. R., Petersen, B., \& Welch, L. S. 2009. Towards more realistic conceptualisations of foreign operation modes. Journal of International Business Studies, 40(9): 1455-1470.

Benito, G. R., Petersen, B., \& Welch, L. S. 2011. Mode combinations and international operations. Management International Review, 51(6): 803-820.

Benito, G. R., Petersen, B., \& Welch, L. S. 2019. The global value chain and internalization theory. Journal of International Business Studies, 50(8): 1414-1423.

Boddewyn, J. J. 2005. Early US business-school literature (19601975) on international business-government relations: its twenty-first-century relevance. In R. Grosse (Ed.), International business and government relations in the 21st century. Cambridge: Cambridge University Press: 25-47.

Boddewyn, J. J. 2016. International business-government relations research 1945-2015: Concepts, typologies, theories and methodologies. Journal of World Business, 51(1): 10-22.

Buckley, P. I. 2020a. China's Belt and Road Initiative and the COVID-19 crisis. Journal of International Business Policy, 3(3): 311-314.

Buckley, P. J. 2020b. China's Belt and Road Initiative: Changing the rules of globalization. Journal of International Business Studies, 51: 279-281.

Chen, J., Fei, Y., Lee, P.T.-W., \& Tao, X. 2019. Overseas port investment policy for China's central and local governments in the Belt and Road Initiative. Journal of Contemporary China, 28: 116. 
Coase, R. H. 1959. The federal communications commission. The Journal of Law and Economics, 2: 1-40.

Coase, R. H. 1960. The problem of social cost. Journal of Law and Economics, 3: 1-44.

Coase, R. H. 1988. The firm, the market, and the law. Chicago: University of Chicago Press.

Delios, A., \& Henisz, W. 2003. Policy uncertainty and sequence of entry by Japanese firms, 1980-1998. Journal of International Business Studies, 34(3): 227-241.

Demsetz, H. 1967. Toward a theory of property rights. American Economic Review, 57: 347-359.

Dykes, B. J., Stevens, C. E., \& Lahiri, N. 2020. Foreignness in public-private partnerships: The case of project finance investments. Journal of International Business Policy, 3: 1-15.

Fagre, N., \& Wells, L. T., Jr. 1982. Bargaining power of multinationals and host governments. Journal of International Business Studies, 13: 9-23.

Fardella, E., \& Prodi, G. 2017. The Belt and Road Initiative impact on Europe: An Italian perspective. China and World Economy, 25(5): 125-138.

Ferrari, C., Tei, A., \& Merk, O. 2015. The governance and regulation of ports: The case of Italy. Discussion Paper. International Transport Forum. Paris: OECD.

Fletcher, M., \& Plakoyiannaki, E. 2011. Case selection in international business: Key issues and common misconceptions. In R. Piekkari, \& C. Welch (Eds.), Rethinking the case study in international business and management research.Cheltenham: Edward Elgar: 171-192.

Foscari, F., Graffi, L., Immordino, M., Seganfreddo, A., Storchi, M. C., \& Tosi, T. 2020. COVID-19-Italy expands Golden Power review of foreign investments. White and Case. https://www. whitecase.com/publications/alert/covid-19-italy-expandsgolden-power-review-foreign-investments. Accessed 10 April 2020.

Foss, K., \& Foss, N. J. 2005. Resources and transaction costs: How property rights economics furthers the resource-based view. Strategic Management Journal, 26(6): 541-553.

Foss, K., \& Foss, N. 2015. Coasian and modern property rights economics. Journal of Institutional Economics, 11(2): 391-411.

Foss, N. J., Klein, P. G., Lien, L. B., Zellweger, T., \& Zenger, T. 2021. Ownership competence. Strategic Management Journal, 42(2): 302-328.

Gong, X. 2019. The Belt and Road Initiative and China's influence in Southeast Asia. The Pacific Review, 32(4): 635665.

Grosse, R. 2005. The bargaining view of government-business relations. In R. Grosse (Ed.), International business and government relations in the 21 st century. Cambridge: Cambridge University Press: 273-290.

Grosse, R., \& Behrman, J. N. 1992. Theory in international business. Transnational Corporations, 1(1): 93-126.

Henisz, W. J., \& Zelner, B. A. 2010. The hidden risks in emerging markets. Harvard Business Review, 18(4): 88-95.

Hennart, J. F. 2009. Down with MNE-centric theories! Market entry and expansion as the bundling of MNE and local assets. Journal of International Business Studies, 40(9): 1432-1454.

Holburn, G., \& Zelner, B. 2010. Political capabilities, policy risk and international investment strategy: Evidence from the global electric power generation industry. Strategic Management lournal, 31(12): 1290-1315.

Houtari, M. 2021. Outlook: Systemic competition on new termsWhat a crisis-driven, globally ascending party state means for European stakeholders. MERICS. https://merics.org/en/ outlook-systemic-competition-new-terms-what-crisis-drivenglobally-ascending-party-state-means. Accessed 20 June 2021.

Huo, W. Chen, P.S.-L., Zhang, W., \& Li, K. X. 2019. International port investment of Chinese port-related companies. International Journal of Shipping and Transport Logistics, 11(5): 430-454.
Hurley, J., Morris, S., \& Portelance, G. 2019. Examining the debt implications of the Belt and Road Initiative from a policy perspective. Journal of Infrastructure, Policy and Development, 3(1): 139-175.

Il Gazzettino. 2014. Grandi Navi, la Serracchiani boccia il porto offshore: «Chi paga?». https://www.ilgazzettino.it/nordest/ primopiano/porto offshore venezia costa serracchiani623711.html. Accessed 20 January 2020.

II Sole 24 Ore. 2016. Renzi, Via della Seta una chance per porti italiani. https://st.ilsole24ore.com/art/mondo/2016-09-04/ renzi-via-seta-chance-porti-italiani-142533.shtml?uuid= ADGC4wEB. Accessed 25 January 2020.

Jenkins, B. 1986. Reexamining the obsolescing bargain-A study of Canada national energy program. International Organization, 40: 139-165.

Kim, J., \& Mahoney, J. T. 2005. Property rights theory, transaction costs theory, and agency theory: An organizational economics approach to strategic management. Managerial and Decision Economics, 26(4): 223-242.

Kindleberger, C. 1969. American business abroad. New Haven: Yale University Press.

Kobrin, S. J. 1987. Testing the bargaining hypothesis in the manufacturing sector in developing countries. International Organization, 41(4): 609-638.

Langley, A. 1999. Strategies for theorizing from process data. Academy of Management Review, 24(4): 691-710.

Lecraw, D. J. 1984. Bargaining power, ownership, and profitability of transnational corporations in developing countries. Journal of International Business Studies, 15(1): 27-43.

Li, J., Van Assche, A., Li, L., \& Qian, G. 2021. Foreign direct investment along the Belt and Road: A political economy perspective. Journal of International Business Studies. https:// doi.org/10.1057/s41267-021-00435-0.

Liu, H., \& Lim, G. 2019. The political economy of a rising China in Southeast Asia: Malaysia's response to the Belt and Road Initiative. Journal of Contemporary China, 28(116): 216-231.

Liu, Z., Schindler, S., \& Liu, W. 2020. Demystifying Chinese overseas investment in infrastructure: Port development, the Belt and Road Initiative and regional development. Journal of Transport Geography, 87: 102812.

Luo, Y., Xue, Q., \& Han, B. 2010. How emerging market governments promote outward FDI: Experience from China. Journal of World Business, 45(1): 68-79.

Moran, T. H. 1974. Multinational corporations and the politics of dependence: Copper in Chile. Princeton: Princeton University Press.

Müllner, J. 2017. International project finance: Review and implications for international finance and international business. Management Review Quarterly, 67(2): 97-133.

Müllner, J., \& Puck, J. 2018. Towards a holistic framework of MNE-state bargaining: A formal model and case-based analysis. Journal of World Business, 53(1): 15-26.

Narins, T. P., \& Agnew, J. 2020. Missing from the map: Chinese exceptionalism, sovereignty regimes and the Belt Road Initiative. Geopolitics, 25(4): 809-837.

Nebus, J., \& Rufin, C. 2010. Extending the bargaining power model: Explaining bargaining outcomes among nations, MNEs, and NGOs. Journal of International Business Studies, 41: 996-1015.

Notteboom, T., \& Yang, Z. 2017. Port governance in China since 2004: Institutional layering and the growing impact of broader policies. Research in Transportation Business and Management, 22: 184-200.

OECD. 2018. OECD Business and Financial Outlook. Paris: OECD. Office of the Leading Group for Promoting the Belt and Road Initiative. 2019. The Belt and Road Initiative progress, Contributions and Prospects 2019. Beijing: Foreign Languages Press.

Piekkari, R., \& Welch, C. 2011. Rethinking the case study in international business and management research. Cheltenham: Edward Elgar. 
Plakoyiannaki, E., Wei, T., \& Prashantham, S. 2019. Rethinking qualitative scholarship in emerging markets: Researching, theorizing, and reporting. Management and Organization Review, 15(2): 217-234.

Port of Venice. 2014. Terminal offshore di Venezia Royal Haskoning consegna il layout definitivo e ottimizza costi e performance.

Quarati, A. 2015. Costa: «ll porto off-shore sarà finanziato dai cinesi». The Medi Telegraph. https://www.themeditelegraph. com/it/shipping/2015/05/06/news/costa-il-porto-off-shoresara-finanziato-dai-cinesi-intervista-1.38168564. Accessed 1 August 2020.

Rajah, R., Dayant, A., \& Pryke, J. 2019. Ocean of debt? Belt and Road and debt diplomacy in the Pacific. Lowy Institute. https:// academicanswers.waldenu.edu/faq/73164. Accessed 12 March 2020.

Ramamurti, R. 2001. The obsolescing 'bargaining model'? MNC-host developing country relations revisited. Journal of International Business Studies, 32: 23-39.

Ramamurti, R., \& Hillemann, J. 2018. What is "Chinese" about Chinese multinationals? Journal of International Business Studies, 49(1): 34-48.

Ritvala, T., Granqvist, N., \& Piekkari, R. 2021. A processual view of organizational stigmatization in foreign market entry: The failure of Guggenheim Helsinki. Journal of International Business Studies, 52: 282-305.

Roberts, J., \& Milgrom, P. 1992. Economics, organization and management. Englewood Cliffs: Prentice-Hall.

Sened, I. 1997. The political institution of private property. Cambridge: Cambridge University Press.

Shepard, W. 2020. Another Belt and Road Project bites the dust as China's New Silk Road continues to struggle. Forbes. https://www.forbes.com/sites/wadeshepard/2020/02/25/ another-belt-and-road-project-bites-the-dust-as-chinas-newsilk-road-continues-to-struggle/\#5892baba53e3. Accessed 1 March 2020

Standish, R. 2019. China's path forward is getting bumpy. The Atlantic. https://www.theatlantic.com/international/archive/ 2019/10/china-belt-road-initiative-problems-kazakhstan/ 597853/. Accessed 1 March 2020.

Stopford, J., \& Strange, S. 1991. Rival states, rival firms: Competition for world market shares. Cambridge: Cambridge University Press.

Summers, T. 2016. China's 'New Silk Roads': Sub-national regions and networks of global political economy. Third World Quarterly, 37(9): 1628-1643.

Sutherland, D., Anderson, J., Bailey, N., \& Alon, I. 2020. Policy, institutional fragility, and Chinese outward foreign direct investment: An empirical examination of the Belt and Road Initiative. Journal of International Business Policy, 3(3): 249272.

Tekdal, V. 2018. China's Belt and Road Initiative: At the crossroads of challenges and ambitions. The Pacific Review, 31(3): 373-390.

Trevisan. 2020. La Cina abbandona il Porto di Venezia, la furia di Venturini: «Governo inetto». II Gazzettino. https://www. ilgazzettino.it/nordest/venezia/assessore_venturini_duro_ con_il_governo_inetto_per_la_perdita_del_porto_della_linea_ diretta_con_la_cina-4980926.html. Accessed 20 September, 2020.

UNCTAD. 2008. World Investment Report 2008: Transnational Corporations and the Infrastructure Challenge. Geneva: UN.

Vachani, S. 1995. Enhancing the obsolescing bargain theory: A longitudinal study of foreign ownership of U.S. and European multinationals. Journal of International Business Studies, 26: $159-180$.

Vernon, R. 1971. Sovereignty at bay: The multinational spread of U.S. enterprises. London: Longman.

Vernon, R. 1981. Sovereignty at bay ten years after. International Organization, 35(3): 517-529.
Voss, H., Buckley, P. J., \& Cross, A. R. 2009. An assessment of the effects of institutional change on Chinese outward direct investment activity. In I. Alon, J. Chang, M. Fetscherin, C. Lattemann, \& J. R. Mclntyre (Eds.), China rules. London: Palgrave Macmillan: 135-165.

World Bank. 2001. World Bank port reform toolkit. Washington, DC: World Bank, Transport Division.

Yu, H. 2017. Motivation behind China's 'One Belt, One Road' Initiatives and establishment of the Asian Infrastructure Investment Bank. Journal of Contemporary China, 26(105): 353-368.

\section{ABOUT THE AUTHORS}

Cristian Luise is a PhD Student in International Business at University of Leeds and Research Fellow at Cà Foscari University of Venice, Department of Management. He uses institutional economics and international political economy to understand multinational enterprises' internationalization behavior and engagement with host-country institutions. He also studies host-country policies toward foreign direct investment absorption.

Peter J. Buckley OBE, FBA, is Professor of International Business, Founder Director of the Centre for International Business, University of Leeds (CIBUL). President of the Academy of International Business 2002-2004. He was awarded the JIBS Platinum Medal 2019 and the British Academy of Management Medal for Research 2021.

Hinrich Voss is the Lallemand: Marcel et RolandChagnon Professor in International Business at HEC Montreal, Canada. His research investigates the interactions and dependencies between MNEs and institutions and focuses on emerging markets. He holds a PhD in International Business from the University of Leeds.

Emmanuella Plakoyiannaki is Chair of International Business at the University of Vienna, Austria. Her research interests refer to SME and family firm internationalization and qualitative research. She has published in various academic outlets including the Academy of Management Review, Journal of International Business Studies, Journal of World Business and Journal of Management Studies, among others.

Elisa Barbieri is Associate Professor of Applied Economics at Cà Foscari University of Venice and part of the Steering Committee of c.MET05 (Italian Centre for Applied Economic Studies). Her research 
interests include industrial policy and human development, industrial policy in East Asia, industrial policy and structural change. She is particularly interested in the interaction between government policy practices and investment choices.

Publisher's Note Springer Nature remains neutral with regard to jurisdictional claims in published maps and institutional affiliations.

Accepted by Ari Van Assche, Deputy Editor, 09 September 2021. This article has been with the authors for four revisions. 